\title{
The Impact of Non-Performing Loans on the Profitability of Listed Euro-Mediterranean Commercial Banks*
}

\author{
Submitted 12/09/19, 1st revision 11/10/19, $2^{\text {nd }}$ revision 30/10/19, accepted 09/11/19
}

\author{
Ayrton Psaila ${ }^{1}$ Jonathan Spiteri ${ }^{2}$, Simon Grima ${ }^{3}$
}

\begin{abstract}
:
Purpose: To analyze the impact of NPLs on listed commercial bank's profitability, in particular their ROA (Return on Assets), in the Euro-Mediterranean area. We aim to determine whether the change in the level of NPLs in listed commercial banks is either positively or negatively impacting the ROA of the concerned banks. Furthermore, knowing that the liquidity and the solvency of a bank are both equally important to maintain a robust financial position, a Liquidity (LQDT) and Solvency (SLVT) ratio were considered to help explain the variances with NPLs and ROA.

Design/Methodology/Approach: We adopted a purposive research design using panel data (2013-2017) from data published on Thomson Reuters Eikon or annual reports of the 35 listed commercial banks in the Euro-Mediterranean region. We used descriptive statistics and four regression models, namely; the Pooled OLS regression model, Fixed Effects (FE), Random Effects (RE) and the Arellano-Bond (AB), through STATA/IC 15.1.

Findings: Findings show that there is a negative impact of NPLs on ROA, indicating that problematic loans negatively impact listed commercial bank's profitability in the EuroMediterranean region. Also, it was indicated that the Solvency ratio (SLVT) is the only controlling factor that can significantly explain variances within NPLs and ROA.

Practical Implications: These results carry with them significant consequences for the bank's financial stability within the Euro-Mediterranean countries and the role of the risk management function of listed commercial banks.
\end{abstract}

Keywords: Non-Performing Loans, Return on Assets, Profitability, Solvency Ratio.

JEL Codes: G20.

Paper type: Research Article.

${ }^{1}$ Graduate Banking and Finance, Department of Banking and Finance, Faculty of

Economics, Management and Accountancy, University of Malta, ayrton.psaila@gmail.com

${ }^{2}$ Lecturer, Department of Insurance, Faculty of Economics, Management and

Accountancy,University of Malta, jonathan.v.spiteri@um.edu.mt

${ }^{3}$ Head and Senior Lecturer, Department of Insurance, Faculty of Economics, Management and Accountancy, University of Malta, corresponding author, simon.grima@um.edu.mt

*This paper is based on the unpublished Thesis by Psaila, A. (2019) "The Impact of NonPerforming Loans on the profitability of listed Euro-Mediterranean commercial banks" supervised by Dr. S. Grima. An earlier version of this article has been presented in ICABE 2019 www.icabe.gr 


\section{Introduction}

The primary activity of a commercial bank is to accept deposits and lend funds to individuals in the form of loans or advances. Hence, their main source of income is purely dependent on the loan activity. If there is a lack of liquidity and a considerable number of individuals start to find it problematic to honor their obligations, loans will take the form of default loans (Azeem et al., 2017). If the said default loans extended beyond a 90-day period, these are then considered as nonperforming loans (NPL) since these loans are no longer able to perform their underlying function adequately. Consequently, since loans can be the main source of income for commercial banks rise in non-performing loans can possibly intrude a lower profitability figure as the bank is now reducing its inflow from credit business.

In the post-financial crisis, the sharp increase in (NPLs) has caught the eye of many authors globally, to attempt explaining how the phenomenon of NPLs can possibly impact the profitability of commercial banks. Quite a few authors such as Kingu, Macha and Gwahula (2018), Messai and Jouini (2013), Anastasiou, Louri and Tsionas (2016), Akter and Roy (2017), and Petkovski, Kjosevski and Jovanovski (2018) have studied the impact of non-performing loans on the profitability of commercial banks. They reveal that a significant negative relationship between nonperforming loans and profitability exists within their selected country or area.

In this study, the focus is on how non-performing loans impact on profitability, specifically for listed commercial banks in the Euro-Mediterranean zone. Our choice of the sample was determined after viewing the statistics published in the form of a notification by the Eurostat, during October 2018. We noted that, in the top ten most highly indebted European countries, six of them formed part of the EuroMediterranean zone. Therefore, if countries in such an area are considered as having a high debt level, non-performing loans can possibly be the underlying factor, since businesses and individuals are more prone to end up not honoring their loan contract obligations. Moreover, if non-performing loans are the reason for such numbers, then analyzing the impact on profitability would be crucial. Therefore, this study would be useful for researchers, risk managers or policy-makers of non-performing loans and profitability or else for commercial banks wishing to expand their business line in the Euro-Mediterranean region.

In this research, tests to determine the impact of non-performing loans vis-à-vis profitability are conducted in 7 Euro-Mediterranean countries, specifically Malta, Italy, Spain, France, Croatia, Greece, and Cyprus, during the period 2013-2017, with a sample size of 35 listed commercial banks (Camilleri et al., 2019). Predominantly, the banking population that fitting our criteria totaled 38 banks when filtering for all commercial type banks in the Euro-Mediterranean region listed on the stock exchange of their country of incorporation. 
In the case that the banks were listed on other stock exchanges, preference was given to the stock exchange of the country of domicile. Subsequently, the sample size of 35 listed commercial banks was determined through the use of an online sample size calculator, where 95\% confidence interval and 5\% margin of error were used (Creative Research Systems, n.d).

Therefore, the fundamental objective of this study is to understand the impact of non-performing loans on the profitability figures of these banks. The novelty and contribution of this paper lies in the fact that we focus on the Euro-Mediterranean region in the post-crisis period, which is particularly important given the impact of the financial crisis and subsequent credit crunch on banking acitivites within these countries. Furthermore, we employ a variety of panel data methods in order to ensure that our findings are robust to different specifications, while also ensuring that our research approach is as transparent and open as possible.

The selection of the Euro-Mediterranean area was deemed as the most representative sample, since in the Eurostat statistics in 2017, it was highlighted that six out of the top ten highly indebted European countries formed part of the Euro-Mediterranean area. Furthermore, in economic theory, countries carrying a high debt ratio (as a \% of GDP) are more prone to sustain a high NPL ratio. Additionally, our selected countries with the exception of Malta were mainly countries with a large share in government deficit (as a \% of GDP). The secondary objectives of this study are as follows:

i. To identify any patterns in profitability and non-performing loan figures during the period from 2013 to 2017 ;

ii. To discover the significance in relationship terms between the dependent variable Return on Assets (ROA) and the independent variable (NPLs) and to discover the significance in variation of the control variables Solvency Ratio (SLVT) and Liquidity Ratio (LQDT) with ROA and NPLs.

iii. To recommend several corrective actions through critical arguments.

Three main hypotheses and alternate hypothesis relating to the connection between ROA and NPLs are constructed:

i. $\quad \mathbf{H}_{1}$ : There is no significant impact of Non-Performing Loans (NPLs) on the Profitability (ROA) of listed commercial banks in the Euro-Mediterranean region.

$\mathbf{H}_{\mathrm{Al}}$ : There is a significant impact of Non-Performing Loans (NPLs) on the Profitability (ROA) of listed commercial banks in the Euro-Mediterranean region. 
ii. $\quad \mathbf{H}_{2}$ : The Liquidity ratio (LQDT) cannot significantly explain the variances with Non-Performing Loans (NPLs) and Profitability (ROA) of a listed commercial bank in the Euro-Mediterranean region.

$\mathbf{H}_{\mathrm{A2}}$ : The Liquidity ratio (LQDT) can significantly explain the variances with Non-Performing Loans (NPLs) and Profitability (ROA) of a listed commercial bank in the Euro-Mediterranean region.

iii. $\quad \mathbf{H}_{3}$ : The Solvency ratio (SLVT) cannot significantly explain the variances with Non-Performing Loans (NPLs) and Profitability (ROA) of a listed commercial bank in the Euro-Mediterranean region.

$\mathbf{H}_{\mathbf{A 3}}$ : The Solvency ratio (SLVT) can significantly explain the variances with Non-Performing Loans (NPLs) and Profitability (ROA) of a listed commercial bank in the Euro-Mediterranean region.

\section{Literature Review}

\subsection{Profitability}

In an ever-evolving dynamic environment within the banking industry, profitability could be a fundamental principle by which banks can determine their level of performance and their efficiency. Having researched financial statements of 10 banks all-residing in Turkey, Anbar and Alper (2011) found that asset size builds a positive relationship with the bank's profitability, which in turn leaves a significant effect. Furthermore, they also advocated that various ratios of loans/assets show that, weak asset quality generates a significantly negative relationship on Return on Assets (ROA). It was also noted that bank loans also had a positive impact on bank's performance as it was considered to be the main source of income. In spite of this, they found that loans did not have a positive relationship with profitability. Using Returns on Equity (ROE) in their studies they also manage to show how real interest rates impinge a positive effect on bank profitability.

The way that a financial system is developed in its economic or financial structure does make a huge distinction in terms of profitability when it comes to banks. Consequently, in a less developed financial framework, a financial system is more likely to be exposed to higher profits. In contrast, those financial systems which are more up to standard and hence, established an 'up and running' financial structure are usually deemed to experience a low profitability situation (Demirgüç-Kunt and Huizinga, 2000).

Dietrich and Wanzenried (2010) show, that when it comes to profitability, there is a substantial variation amongst commercial banks even within the same country. To corroborate the aforesaid statement and further show the rationale of these variations, an analysis was specifically conducted on 453 commercial banks all residing in Switzerland over a 10-year period. The analysis seemed to predict that banks that had a considerable amount of capital seemed to be the most profitable 
ones. Another contributable factor throughout this analysis explains how the rapid growth in the banks' loan capacity is growing even faster than that of the market, eventually, this could leave a positive effect on the bank's overall profitability. Other significant factors, which were mentioned during this study, include the GDP growth rate, which turns out to produce a positive relationship.

Moreover, the effective tax rate and the market concentration rate were also mentioned, whereby these two turned out to have a negative impact on the bank's profitability. Similarly, Curak, Poposki, and Pepur (2012) and Athanasoglou, Brissimis and Delis (2005), also highlight the importance of the aforementioned factors throughout their studies. They focus their analysis on the basis of bankspecific, industry-specific and macro-economic factors in Macedonia and Greece respectively. They then elaborate further in their analysis of the banks' profitability determinants. Management efficiency and capital adequacy growth are both major drivers for the long-term profitability of a bank, as they considerably influence all measures of profitability mentioned in Căpraru and Ihnatov (2014) study. Whereby, these show that Return on Equity (ROE), (ROA) and Net Interest Margin (NIM) are all affected by the previously mentioned drivers. Also, further determinants impacting profitability were also highlighted, and thus it was concluded that credit risk and inflation play a major role in determining ROA and ROE, whereas, the size of the bank was the sole determinant that impacted the most on the (NIM).

Petria, Căpraru, and Ihnatov (2015) also argued that credit risk and management efficiency have a significant influence on banks' profitability. They note that this study explained a wider context than the previous study, as it is based on all of the twenty-seven countries in the European Union, whilst the other was only based on five selected Central and Eastern European Countries. Despite, the several commonalities the two studies show some controversies. In the first study, it was advocated that the size of the bank negatively affects the NIM and suggests that when banks are larger in nature this would show that the NIM would be relatively small. Conversely, in the last study it was concluded that the size of the bank only affects the ROA in a small way, does not have any significant effect.

\subsubsection{Measures of Profitability}

As Căpraru and Ihnatov (2014) aforementioned, proxies of profitability such as (ROA), (ROE) and (NIM) are measures of profitability which are used extensively. In fact, Petria, Căpraru, and Ihnatov (2015), Athanasoglou, Brissimis and Delis (2005) and Anbar and Alper (2011 use such profitability measures, specifically in their analysis. Despite such commonly used measures, proxies of profitability sometimes diverge among studies, as these are consequently determined through other underlying factors such as, size of bank and inflation amongst other factors, which are important for the overall intention of the study.

Căpraru and Ihnatov (2014), further corroborates the aforesaid measures of profitability by classifying ROA, ROE, and NIM as the dependent variables, 
whereby these are moreover explained through independent variables. Such independent variables are derived from additional underlying factors comprising of, bank-specific factors, banking system-specific factors, and macroeconomic factors. The first factor being the internal factor, whilst the latter two being the external factors. Athanasoglou, Brissimis and Delis (2005) also argue along these lines, as they claim that profitability measures are also determined as a function of internal and external factors. Again, similar to other literatures, they appear to emphasise the fact that there is a relationship between profitability and bank-specific, industryrelated and macroeconomic factors, which they serve as a computational measure for profitability.

It is further described that ROA stands for the Return on Average Assets which thereby explains the net profit figure as a function of the average assets. Similarly, ROE is defined as the Return on Average Equity which explains the net profit, this time as a function of the average common stock equity. The last profitability measure, the NIM, represents the change among interest income in relation to the interest expense as a function of total bank assets (Căpraru and Ihnatov, 2014).

The only discrepancy between the two studies is, that Căpraru and Ihnatov (2014) uses proxies of profitability as dependent variables which are explained by other factors, whilst in an opposing manner, Athanasoglou, Brissimis, and Delis (2005) focuses on the idea that such proxies of profitability are classified as independent variables, hence explaining the determinants of profitability themselves this time.

\subsection{Non-Performing Loans (NPLs)}

The European Central Bank (2016), explains briefly what the definition of a nonperforming loan is, by claiming that, a loan is classified as a bad debt or nonperforming in the case when the loan has been overdue by more than 90 days. A non-performing loan could be subject to various factors that enable it to convert from a usual performing loan. When studying the relationship between the increase in non-performing loans and the real economic performance of Japan, Inaba et al. (2002) emphasized that the rise in non-performing loans is the result of a few important key factors. They emphasised that a radical growth in non-performing loans was evidenced when land prices started to fall, which consequently impacted negatively on the firm's statement of the financial position. Moreover, the increase was further reflected in the real economic performance as the rise in non-performing loans created an unforeseen cessation in the banking industry, mainly due to a credit crunch and also because of forbearance lending practices.

A study conducted by Hepssen and Vatansever (2013), highlights the main determinants and the relationship between the non-performing loan ratio together with specific banks and various macro-economic factors. During this study, the Ordinary Least Squares (OLS) estimator to run the regression analysis was used, based on time-series data, ranging from January 2007 to April 2003. This analysis 
established which factors impact the non-performing loan ratio either positively or negatively. It was concluded that determinants such as the Industrial Production Index (IPI) and the Inefficiency ratio of all banks (INEF), negatively impacted the non-performing loan ratio. Conversely, Unemployment Rate (UR), Return on Equity (ROE) and the Capital Adequacy Ratio (CAR) all had a positive effect on the nonperforming loan ratio.

Evidently, non-performing loans demonstrate how their contribution to the macroeconomy depends on various independent factors in the overall bank activity. The real GDP growth was also considered to be a major element impacting on nonperforming loans. Beck, Jakubik, and Piloiu (2013) in fact, substantiated the aforesaid impact by conducting an econometric analysis. It was argued that, if the real GDP was the main cause for the changes in non-performing loan ratios, this subsequently could have resulted in an adverse situation when considering bank quality with regards to the deterioration in the global economic activity. Correspondingly, apart from the various factors, which determine the increase in non-performing loans, it was also emphasized that what distresses them the most is when the exchange rates depreciate in an economy, which is highly reliant on lending activity, specifically with regards to foreign currencies. An example that describes such situation, is the case of Poland, Croatia, and Hungary respectively.

Louzis, Vouldis, and Metaxas (2012), also argue on the same idea, but in their study they also make a distinction with regards to the category of loans, as they believe that determinants vary according to the loan category. Correspondingly, apart from the macro-economic factors and the loan category, this study also emphasizes that the quality of management is a key player that regulates the degree in which loans are classified as non-performing ones. Thus, this should be managed in the most comprehensive way possible.

Grima et al. (2018) investigate the relationship between macroeconomic factors and the non-performing loan levels in commercial banks. Unlike other authors, during their argumentation, they do not focus on one specific country but in fact, their study takes into perspective a sample of ten transition countries all-residing in Europe. To analyze such a relationship, they conducted various econometric models over the span of ten years ranging from 2006 to 2016. Evidently, inflation, which other authors did not consider, was observed to be a significant determinant impacting-on non-performing loans.

Their findings show that inflation has a significantly negative relationship with nonperforming loans, thereby implying that during high inflation periods, the real burden of loan repayments decreases. In broad terms it means, that people are more likely to honor their obligations in the loan contract.

Some authors segmented the non-performing loans between macro-variables and banking related variables, Kupčinskas and Paškevičius (2017). Findings here 
revealed that macro-variables such as unemployment rate and real GDP growth are more viable in the situation of explaining any looming changes in the asset quality of the portfolios. Whereas, other macro-variables including Households Disposable Income and the Harmonized Index for Consumer Prices reveal that these are insignificant. On the other hand, the banking-related variables such as profitability proxies (ROA, ROE, NIM), show that they are not relevant enough in explaining changes in non-performing loans.

Žiković, Žiković and Blecich (2015) segment their study by separately analyzing the relationship between the non-performing loan ratio and the macro-economic performance of Croatia under two loan categories: household loans and corporate loans. Again, results are similar to the other studies and non-performing loan determinants are generally on the same lines. Cucinelli (2015) argues on the same idea of Žiković, Žiković and Blecich (2015) using a different approach, whereby in this case apart from the fact that the country is different (Italy), the author attempts to highlight the difference that cooperative and commercial banks show with regards to their bank lending behavior.

Siakoulis (2017) advocates that in an economy, fiscal policies will significantly affect NPL due to reductions in the government spending of a country or the increase in tax revenues, or both. Subsequently, this study shows that such austerity measures will in actual fact translate into a boundary for the loan servicing capacity of both households and businesses, thereby this substantiates the hypothesis that fiscal policy appears to have a significant effect on the initiation stage of nonperforming loan formation. Zhang et al. (2014) highlight the importance that moral hazard has on the non-performing loans ratio. It was claimed, that those banks, which in the past have experienced a high ratio of non-performing loans are more likely to result in moral hazard.

\subsection{The Relationship between Non-Performing Loans and Profitability}

A performing loan will provide a bank with the interest income it needs to make a profit and extend new loans. When customers do not meet their agreed repayment arrangements for 90 days or more, the bank must set aside more capital on the assumption that the loan will not be paid back. This reduces its capacity to provide new loans. If a bank has too many bad loans on its balance sheet, its profitability will suffer because it will no longer earn enough money from its credit business. In addition, it will need to put money aside as a safety net in case it needs to write off the full amount of the loan at some point in time (European Central Bank, 2016).

In their 'financial sector assessment program' within the Euro area, the International Monetary Fund (IMF) elaborates on the impact of Non-Performing Loans (NPLs) on profitability.

The most robust determinants of bank profitability across large euro area banks appear to be real GDP growth and the NPL ratio after accounting for other factors. 
Higher growth by the order of 1 percentage point is associated with a 15-35 basis point rise in ROA, which is considerable given that average ROA over 2007-2016 was 34 basis points. At the same time, recall that growth over the sample period had an average of 0.8 percent - in other words, the increase in growth by a percentage point is large. A 1 percentage point decline in the NPL ratio can lift ROA by about $4-9$ basis points. (International Monetary Fund, 2018)

Akter and Roy (2017), argued, that since lending is an integral part of the banks' ongoing activity, it is imperative that commercial banks keep an eye on the overdue funds lent out, which periodic repayments are overdue. This study further delves into the relationship between non-performing loans and profitability and their effect on each other. It showed that, if banks are unable to recoup the funds given to the borrowers, this may have a ripple effect on public confidence. That is if banks do not collect the funds which are overdue this would consequently lead to the public losing confidence in the concerned banks. Eventually, this will force a bank-run, which will further aggravate the situation, as it will subsequently result in a negative impact on profitability. Therefore, this shows that non-performing loans and profitability do have a relationship with each other and in fact, there is an inverse relationship between the two factors. In a nutshell, this further validates the argument that lending is a core pillar within the on-going commercial banks' activity because if loans are classified as non-performing ones and such amounts increase, it would significantly reduce profitability by a substantial amount.

Christaria and Kurnia (2016), also took the same positions and similarly find that if banks do not focus on preserving a manageable level of non-performing loans, this would affect the level of public confidence which will in turn also affect the risks and profitability of the concerned banks. Profitability measures particularly the (ROA), appear to be the most significant representation which impacts NPL in this stance. Indeed, Akter and Roy (2017), Anastasiou, Louri and Tsionas (2016), Kingu, Macha and Gwahula (2018), Kirui (2014), Messai and Jouini (2013), and Petkovski, Kjosevski and Jovanovski (2018) all found out that (ROA) negatively impacted NPL. One study that substantiates such an impact is the one by Anastasiou, Louri and Tsionas (2016), where they found that banks that are backed by strong profitability are usually deemed to be more risk-averse towards participating in unsafe and high-risk activities.

\section{Methodology}

\subsection{Data and Sources}

For the purpose of this study 35 listed commercial banks were chosen. The sample size of 35 is based on the number of commercial banks listed on the stock exchange website of their respective countries and on the assumption that valid commercial banks listed on the stock exchange should be domiciled in that same country. Where the situation of large bank groups listed on several stock exchanges was present, the 
valid listing considered was that of the country where the banks were domiciled. The number of banks that were considered to fit such a criterion totaled 38 listed commercial banks across the seven countries selected to represent the EuroMediterranean region. In order, to select the most representative sample size for the study, a sample size calculator was used with 95\% confidence interval and 5\% margin of error. Subsequently, such sample size calculator computed the ideal sample size to be that of 35 .

In view of those countries which had a larger bank population, their banks contributed to a larger proportion of the sample size selected. The selection of participants in the sample chosen for this study was based on a non-probability sampling approach, more specifically purposive sampling (Showkat and Parveen, 2017). This illustrates that banks were selected with an explicit purpose in mind, that of choosing the listed commercial type of banks. Commercial type, as these banks are the ones which are involved the most in the deposit and lending activity and also comprise of the main financial institutions (Ferrante, 2012) and (Ongore and Kusa, 2013). Correspondingly, they are to be listed as these banks are deemed to be the most profitable ones (Lipunga, 2014).

Based on literature it was considered as pertinent to use secondary and panel data (Grima et al., 2018; Akter and Roy 2017). In fact, this research mostly used data published by Thomson Reuters Eikon, but when there were instances where data was inconsistent, the audited financial statements of each bank were used. Furthermore, the choice of sample selection was constructed on the notion of a notification released by the Eurostat with regards to the provision of deficit and debt data for 2017.

The said notification is represented more clearly in Figures 1 and 2 below. The selection of the Euro-Mediterranean area was deemed as the most representative sample, since in the 2017 it was showed that six out of the top ten highly indebted European countries formed part of the Euro-Mediterranean area. Generally, as noted in the literature above, countries carrying a high debt ratio are more likely to sustain a high NPL ratio. Additionally, we also chose based on countries with the largest share in government deficit (as a \% of GDP) (Eurostat, 2018).

We believe that actually selected countries based on such statistics would be more crucial and relevant to our analysis. Also, since the deficit/surplus data and debt data are both already based on a \% of GDP (the element of GDP is instilled into the reasoning of sample selection), GDP was not included as another independent or control variable in our econometric model. Moreover, we felt that this would not serve our purpose of understanding the impact of a country in particular (rather than the impact on the whole region). 
Figure 1. Government Debt (\% of GDP) based on 2017

\section{Government Debt (\% of GDP)}

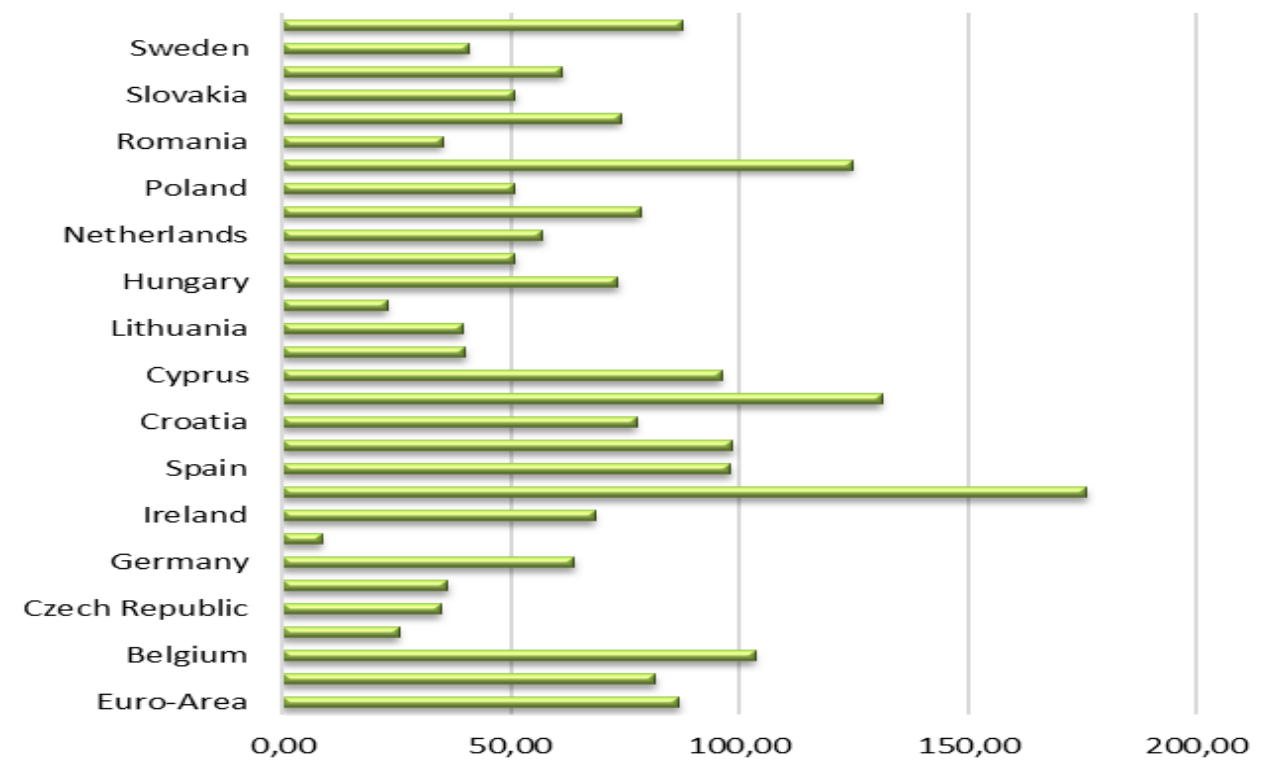

Source: Adapted from data published by the Eurostat.

Data for NPL, ROA, loan-to-deposit ratio and the equity-to-assets ratio were collected respectively from the Thomson Reuters Eikon. When data for NPL was inconsistent during the collection process, this was then extracted manually from the annual reports of each respective bank. Data collected from annual reports include the 'total gross loans receivables and advances' figure and the 'NPL' figure, to compute the NPL ratio as worked out by Thomson Reuters and The World Bank. Below is the equation used to compute the aforesaid:

\section{Bank NPLs (\% of total gross loans)

$$
=\frac{\text { NPL figure }(€ \text { millions })}{\text { Total value of loan portfolio }(€ \text { millions })}
$$

Where; the total value of the loan portfolio should include NPLs before any deductions of explicit loan-loss provisions and the NPL figure must be the gross value of the loan as recognized on the balance sheet and not as the amount recorded to be overdue (The World Bank Group, 2018).

For the analysis 35 listed commercial banks in 7 Euro-Mediterranean countries were selected: 
Figure 2. Government Deficit (-)/Surplus (+) (\% of GDP) based on 2017

\section{Government Deficit (-)/ Surplus (+) (\% of GDP)}

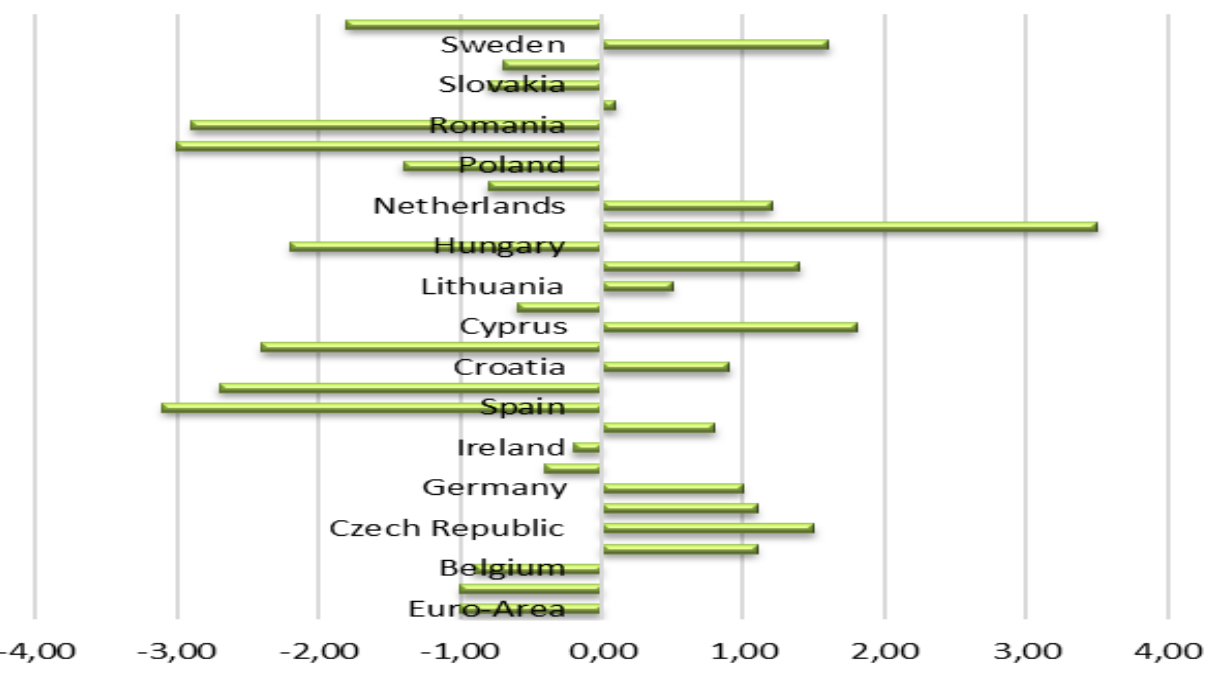

Source: Adapted from data published by the Eurostat.

Table 1. Listed commercial banks selected to represent the sample

\begin{tabular}{|l|l|l|l|}
\hline Bank Code & Bank & Country & $\begin{array}{l}\text { Stock } \\
\text { Exchange }\end{array}$ \\
\hline HPB & Hrvatska Poštanska Banka D.D. & Croatia & $\begin{array}{l}\text { Zagrebačka } \\
\text { Burza }\end{array}$ \\
\hline PBZ & Privredna Bank Zagreb D.D. & Croatia & $\begin{array}{l}\text { Zagrebačka } \\
\text { Burza }\end{array}$ \\
\hline SLTB & Slatinska Banka D.D. & Croatia & $\begin{array}{l}\text { Zagrebačka } \\
\text { Burza }\end{array}$ \\
\hline ZBB & Zagrebačka Banka D.D. & Croatia & $\begin{array}{l}\text { Zagrebačka } \\
\text { Burza }\end{array}$ \\
\hline BOC & Bank of Cyprus & Cyprus & $\begin{array}{l}\text { Cyprus } \\
\text { Stock } \\
\text { Exchange }\end{array}$ \\
\hline HLB & Hellenic Bank P.C.L. & $\begin{array}{l}\text { Cyprus } \\
\text { Stock } \\
\text { Exchange }\end{array}$ \\
\hline BNP & BNP Paribas S.A. & Cyprus & $\begin{array}{l}\text { Euronext } \\
\text { Paris }\end{array}$ \\
\hline BPCE & Banque Populaire Caisse d'Épargne S.A. & France & $\begin{array}{l}\text { Euronext } \\
\text { Paris }\end{array}$ \\
\hline CRA & Crédit Agricole S.A. France & France & $\begin{array}{l}\text { Euronext } \\
\text { Paris }\end{array}$ \\
\hline
\end{tabular}




\begin{tabular}{|c|c|c|c|}
\hline CRM & Crédit Mutuel & France & $\begin{array}{l}\text { Euronext } \\
\text { Paris }\end{array}$ \\
\hline SOG & Société Générale S.A. & France & $\begin{array}{l}\text { Euronext } \\
\text { Paris }\end{array}$ \\
\hline APB & Alpha Bank S.A. & Greece & $\begin{array}{l}\text { Athens Stock } \\
\text { Exchange }\end{array}$ \\
\hline EBE & Eurobank Ergasias S.A. & Greece & $\begin{array}{l}\text { Athens Stock } \\
\text { Exchange }\end{array}$ \\
\hline NBG & National Bank of Greece & Greece & $\begin{array}{l}\text { Athens Stock } \\
\text { Exchange }\end{array}$ \\
\hline PRB & Piraeus Bank S.A. & Greece & $\begin{array}{l}\text { Athens Stock } \\
\text { Exchange }\end{array}$ \\
\hline BCR & Banca Carige S.p.A. & Italy & $\begin{array}{l}\text { Borsa } \\
\text { Italiana }\end{array}$ \\
\hline BMPS & Banco Monte Dei Paschi Di Siena & Italy & $\begin{array}{l}\text { Borsa } \\
\text { Italiana }\end{array}$ \\
\hline $\mathrm{BPCV}$ & Banca Piccolo Credito Valtellinese S.p.A. & Italy & $\begin{array}{l}\text { Borsa } \\
\text { Italiana } \\
\end{array}$ \\
\hline BPDS & Banco Popolare Di Sondrio S.C.P.A. & Italy & $\begin{array}{l}\text { Borsa } \\
\text { Italiana }\end{array}$ \\
\hline BDDB & Banco Di Desio E Della Brianza S.p.A. & Italy & $\begin{array}{l}\text { Borsa } \\
\text { Italiana }\end{array}$ \\
\hline BPER & BPER Banca S.p.A. & Italy & $\begin{array}{l}\text { Borsa } \\
\text { Italiana }\end{array}$ \\
\hline CRE & Credito Emiliano S.p.A. & Italy & $\begin{array}{l}\text { Borsa } \\
\text { Italiana }\end{array}$ \\
\hline ISP & Intesa Sanpaolo S.p.A. & Italy & $\begin{array}{l}\text { Borsa } \\
\text { Italiana }\end{array}$ \\
\hline UCR & UniCredit S.p.A. & Italy & $\begin{array}{l}\text { Borsa } \\
\text { Italiana }\end{array}$ \\
\hline UBI & Unione di Banche Italiane S.p.A. & Italy & $\begin{array}{l}\text { Borsa } \\
\text { Italiana }\end{array}$ \\
\hline BOV & Bank of Valletta & Malta & $\begin{array}{l}\text { Malta Stock } \\
\text { Exchange }\end{array}$ \\
\hline HSBC & HSBC Malta & Malta & $\begin{array}{l}\text { Malta Stock } \\
\text { Exchange }\end{array}$ \\
\hline BBVA & Banco Bilbao Vizcaya Argentaria & Spain & $\begin{array}{ll}\text { Bolsa } & \text { de } \\
\text { Madrid } & \\
\end{array}$ \\
\hline BDS & Banco De Sabadell S.A. & Spain & $\begin{array}{ll}\text { Bolsa } & \text { de } \\
\text { Madrid } & \\
\end{array}$ \\
\hline BSN & Banco Santander & Spain & $\begin{array}{ll}\text { Bolsa } & \text { de } \\
\text { Madrid } & \\
\end{array}$ \\
\hline BIA & Bankia S.A. & Spain & $\begin{array}{ll}\text { Bolsa de } \\
\text { Madrid }\end{array}$ \\
\hline BIN & Bankinter S.A. & Spain & $\begin{array}{ll}\text { Bolsa } & \text { de } \\
\text { Madrid } & \\
\end{array}$ \\
\hline $\mathrm{CXB}$ & CaixaBank S.A. & Spain & $\begin{array}{ll}\text { Bolsa de } \\
\text { Madrid }\end{array}$ \\
\hline
\end{tabular}




\begin{tabular}{|l|l|l|l|}
\hline LRB & Liberbank S.A. & Spain & $\begin{array}{l}\text { Bolsa de } \\
\text { Madrid d de }\end{array}$ \\
\hline UNCB & Unicaja Banco S.A. & Spain & $\begin{array}{l}\text { Bolsa } \\
\text { Madrid }\end{array}$ \\
\hline
\end{tabular}

Source: Adapted from the respective stock exchanges.

Data for all banks were collected annually based on the financial year of each respective bank. Data for Croatian banks, in particular, was collected in the Euro currency for accuracy of comparison amongst banks in the sample. FX currency (HRK/EUR) collected as on 27/02/2019.

Despite all banks represented in the sample adhere to the same non-performing loan conventions and accounting standards i.e. IAS 39 and IFRS 9, different methodologies are still present across different countries. Therefore, heightened responsiveness to check which figures to include in the non-performing loan (\% of total gross loans) calculation was raised. In fact, some banks did not include the NPL figure or ratio specifically. Instead, they referred to these loans as either 'nonperforming exposures' or 'impaired loans and advances'. Particular attention to focus on bank figures rather than group figures were also given, especially when group consolidated annual reports were also provided.

In this study, we used STATA/IC 15 software to estimate panel-specific regression models, namely the Pooled OLS regression model, Fixed and Random Effect estimation models respectively, as well as the Arellano-Bond framework. Consequently, two post-estimation tests were conducted, 1) the Hausmann specification test was conducted to show whether the Fixed or Random Effect model is the appropriate estimation model, whereas 2) the Breusch-Pagan (Lagrange Multiplier) Test was conducted to determine the preferred model for our data between the Random-Effects model and the Pooled OLS regression model.

\subsection{Data Analysis}

The primary objective of the below econometric model is to analyze the relationship between NPL and profitability. Kingu, Macha, and Gwahula (2018) attempted to conduct a similar study about such relationship using the same econometric model but applying the case to listed commercial banks in Tanzania. Throughout this study, the same econometric model was used but, with particular focus on listed commercial banks in the Euro-Mediterranean region. The econometric model explaining the aforesaid relationship is defined in the equation below:

$\mathrm{ROA} A_{i t}=\alpha+\beta_{1} N P L_{i t}+\gamma_{2} L Q D T_{i t}+\gamma_{3} S L V T_{i t}+\varphi_{i}+\epsilon$

Where:

$\boldsymbol{R} \boldsymbol{O} \boldsymbol{A}_{i \boldsymbol{t}}=$ Return on Assets of bank " $\boldsymbol{i}$ " at time period " $\boldsymbol{t}$ ";

$\boldsymbol{N P L _ { i t }}=$ Non-performing loans of bank " $\boldsymbol{i}$ " at time period " $\boldsymbol{t}$ "; 
$\boldsymbol{L Q D T}_{i t}=$ Loan to Deposit Ratio of bank " $\boldsymbol{i}$ " at time period " $\boldsymbol{t}$ ";

$\boldsymbol{S L V T}_{\boldsymbol{i t}}=$ Equity/Total Assets of bank " $\boldsymbol{i}$ " at time period " $\boldsymbol{t}$ ";

$\boldsymbol{\alpha}=$ constant parameter (intercept);

$\boldsymbol{\beta}=$ coefficients of independent variable;

$\gamma=$ coefficients of control variables;

$\varphi_{i}=$ captures bank-specific fixed effects

$\boldsymbol{\epsilon}=$ random error term;

$\boldsymbol{t}=$ a specific time-period being observed $(2013-2017) \therefore 1 \leq t \leq 5$

$\boldsymbol{i}=$ a particular listed commercial bank.

In the econometric model, we use the bank's level of Return on Assets as the dependent variable, the level of the bank's Non-Performing Loans as of the core explanatory variable, together with two control variables being, a liquidity ratio and a solvency ratio.

Return on Assets: $\boldsymbol{R O A}_{i t}$ can be defined as a proxy of profitability and as such it is used broadly by various authors as a dependent variable in order to evaluate the overall bank's profitability affected by some explanatory variables (Căpraru and Ihnatov, 2014) (Petria, Căpraru, and Ihnatov, 2015) (Athanasoglou, Brissimis and Delis, 2005) (Anbar and Alper, 2011).

Non-Performing Loans: $N \boldsymbol{P L}_{\boldsymbol{i t}}$ is the core indicator affecting profitability in this model and therefore changes in this figure will intrude a change in the dependent variable i.e. ROA. Messai and Jouini (2013) used NPL as an explanatory variable to find the effect on profitability.

Liquidity ratio: $L Q D T_{i t}$ in the context of this study, the liquidity ratio deemed as the most representable is the loan-to-deposit ratio. This ratio is used as a control variable throughout this model, as it will show that the higher the loan ratio relative to that of the deposits, the lower the liquidity level of the bank would be. (Kingu, Macha and Gwahula, 2018)

Solvency ratio: SLVT it in the setting of this study, the equity to total assets ratio was used. This ratio together with the liquidity ratio will be acting as a control variable in the econometric model of this study. Moreover, as Kingu, Macha, and Gwahula (2018) illustrated this can be a representative variable of a financial risk indicator in this model and concurrently as a capital adequacy ratio for banks.

We estimate equation (1) using Pooled OLS (POLS), Random Effects (RE), Fixed Effecs (FE) and the Arellano-Bond Estimator.

Clustered-Robust standard errors are used throughout. We also run the Shapiro-Wilk normality test to test for the normality of our errors. The economic rationale of this study presumes that causality may run in a reciprocal direction, meaning that our 
explanatory variable causes the dependent variable and vice versa the dependent variable causes the explanatory variable. Subsequently, the parameters in our model are highly probable that they may be correlated with the residual term i.e. endogeneity (Allison, 2005). Thus, Arellano and Bond (1991) ease such causation concerns by using the Generalized Method of Moments (GMM) estimator, to determine whether reverse causality is present in such panel data, while also controlling for any presence of endogeneity which may be caused by the tenacity in the time-series component of the dependent variable. In our case, it is likely that reverse causality may exist between our dependent and independent variables, while it is also possible that NPLs may have a dynamic impact on future NPLs, with current NPLs propagating further NPLs. The use of the Arellano-Bond estimator also acts as a further robustness check to ensure that our findings hold under different specifications and modeling assumptions.

\section{Results and Analysis}

As seen in Table 2, there is a minimum (ROA) of $-5.40 \%$ which relates to Banca Carige S.p.A. (BCR), a listed commercial bank in Italy. In 2013, BCR managed to overturn the average net income achieved of $€ 20$ million in 2012 to an average net loss of $€ 1.7$ million in 2013 . This net loss is mainly driven by an approximately $50 \%$ increase in the loan loss provisions accounted for, compared to that of the previous year and also due to the sudden increase in non-interest expenses. On the other hand, the maximum ROA valued at $3.50 \%$ was realised by Alpha Bank S.A. (APB) in Greece. The mean ROA value was almost to $0 \%$ but slightly on the negative side.

The mean (NPL) ratio was $18.25 \%$, which ranges from a minimum figure of $1.55 \%$ by Slatinska Banka D.D. (SLTB) in Croatia, to an excessively high figure of $64.07 \%$ by Piraeus Bank S.A. (PRB) in Greece. Consequently, this agrees with the rationale for country selection discussed above, where banks were selected upon the notion of the financial strength of their domicile country. Hence, we have countries, which realize a surplus or else a deficit, also there are countries which are excessively indebted compared to others. Therefore, such maximum and minimum results reflect seamlessly what the economic theory states, that highly indebted countries such as Greece in this situation, are more prone to higher levels of non-performing loans. Moreover, the spread in the range of minimum and maximum figures is backed by the financial strength of the bank's respective countries.

In the below figures constructed manually through STATA/IC 15.1, scatterplots are used to map out the relationship between ROA and NPL amongst all the 35 listed commercial banks and also between the countries selected to represent the EuroMediterranean region. Furthermore, line graphs are used to explain clearly in practice the variation in the level of ROA and NPL throughout the years and also, to a further extent show how the level of NPL varies amongst the listed commercial banks; their respective country of domicile where they are listed and also during the analysed period i.e. 2013 -2017. In Figure 3 below, the relationship between ROA 
and NPL of each listed commercial bank is represented graphically by computing a 5-year average for variables through STATA/IC 15.1.

Table 2. Descriptive statistics

\begin{tabular}{|c|c|c|c|c|c|c|c|c|}
\hline$\frac{\frac{0}{2}}{\frac{\pi}{\pi}}$ & 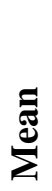 & 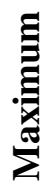 & 㤩 & 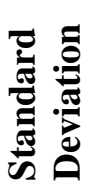 & 营 & 苞 & 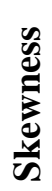 & $\frac{n}{30}$ \\
\hline$\underset{\bigotimes}{\mathbb{\alpha}}$ & $\begin{array}{l}8 \\
8 \\
8 \\
0\end{array}$ & 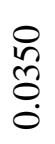 & 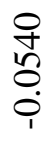 & 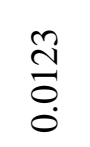 & $\begin{array}{l}8 \\
8 \\
8\end{array}$ & $\begin{array}{l}0 \\
\text { ֻ } \\
\text { ठ }\end{array}$ & 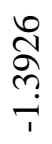 & $\frac{m}{\stackrel{0}{0}}$ \\
\hline $\overrightarrow{\mathbf{Z}}$ & $\begin{array}{l}n \\
\infty \\
\infty \\
0\end{array}$ & $\begin{array}{l}\text { So } \\
\text { fo } \\
0\end{array}$ & $\frac{n}{n}$ & $\begin{array}{l}\infty \\
\infty \\
\\
0\end{array}$ & $\begin{array}{l}\stackrel{9}{\Xi} \\
\stackrel{0}{0}\end{array}$ & $\frac{8}{2}$ & 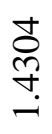 & $\begin{array}{l}0 \\
8 \\
? \\
\text { ? }\end{array}$ \\
\hline ڤ્) & $\begin{array}{l}\vec{\infty} \\
\stackrel{\alpha}{o} \\
\stackrel{o}{0}\end{array}$ & $\begin{array}{l}8 \\
\infty \\
\sim \\
i\end{array}$ & 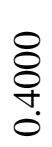 & 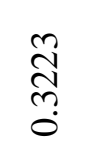 & 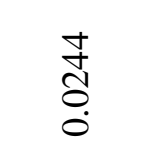 & $\begin{array}{l}8 \\
\infty \\
\infty \\
0\end{array}$ & 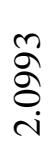 & $\begin{array}{l}\stackrel{g}{8} \\
\vdots \\
0\end{array}$ \\
\hline$\frac{5}{3}$ & $\begin{array}{l}\overline{0} \\
\stackrel{0}{0} \\
0\end{array}$ & 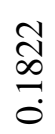 & 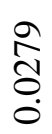 & 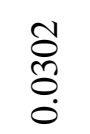 & 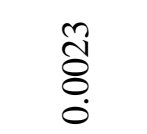 & $\begin{array}{l}0 \\
\infty \\
0 \\
0 \\
0\end{array}$ & 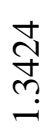 & $\begin{array}{l}\infty \\
\text { \&े } \\
\dot{+}\end{array}$ \\
\hline
\end{tabular}

Source: Authors Compilation.

This scatterplot is essential as it maps all the listed commercial banks representing the sample by their performance through ROA and their level of risk attached to the accumulation of NPLs throughout the years. It is evidently shown that Piraeus Bank S.A. (PRB) in Greece was the worst performer, whilst the best performer was Bank of Valletta (BOV) in Malta. Indeed, in Figure 4 below this shows that the worst performer by country was Greece and the best performer by country was Malta. Consequently, this graphical representation of results agrees with the results of the notification that the Eurostat released on October 2018, where it indicated that Greece was the highest indebted country in Europe as in 2017 whereas, Malta secured the largest surplus figure as at 2017.

\section{Shapiro-Wilk Normality test:}

In the Shapiro-Wilk test for normality, the probability value (p-value) signifies whether there is the presence of normality in our data. If the p-value is greater than 0.05 then, our data is said to be normally distributed. Therefore, if we look at the $\mathrm{p}$ value with regards to the variables in this model, we can say that none of the 
variables indicate that our data is normally distributed and hence we can reject the hypothesis for all the variables that our data is normally distributed.

Figure 3. Scatterplot showing the relationship between ROA and NPL for each listed commercial bank

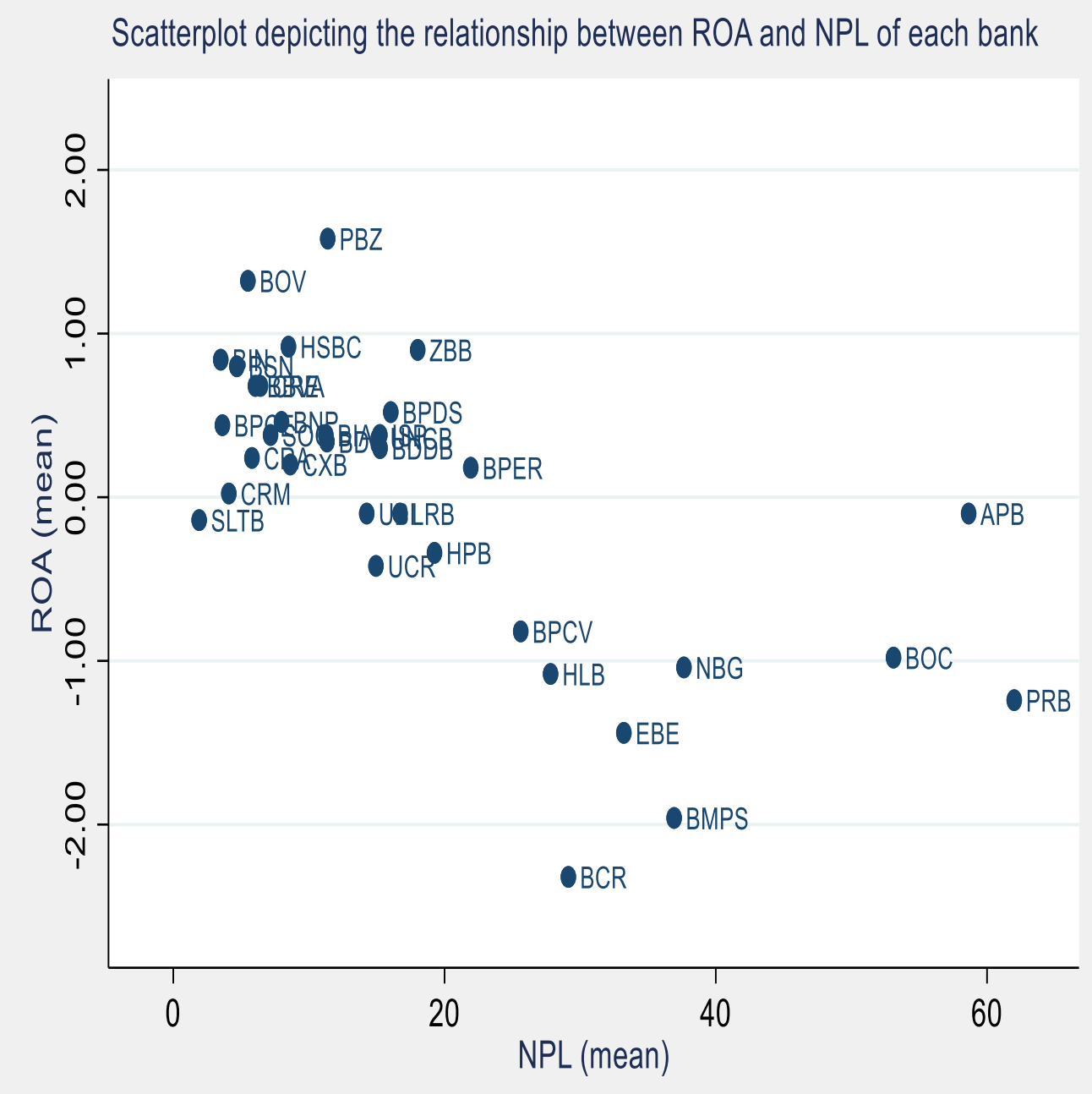

Source: Authors' Compilation.

The median values which are represented in $\mathrm{V}$ sometimes show us more than the actual $\mathrm{W}$ test statistic as it determines the index for departure from normality. In normally distributed data this median value of $\mathrm{V}$ is generally 1 . Indeed, if we look at our data, we can conclude that the departure from the number 1 and moreover from the normality assumption is considerably evident in our results, as the $\mathrm{V}$ median values range from an average of 16 to an average of 23. The results showing the Shapiro-Wilk normality test are illustrated in Table 3. 
Figure 4. Scatterplot showing the relationship between ROA and NPL for each country

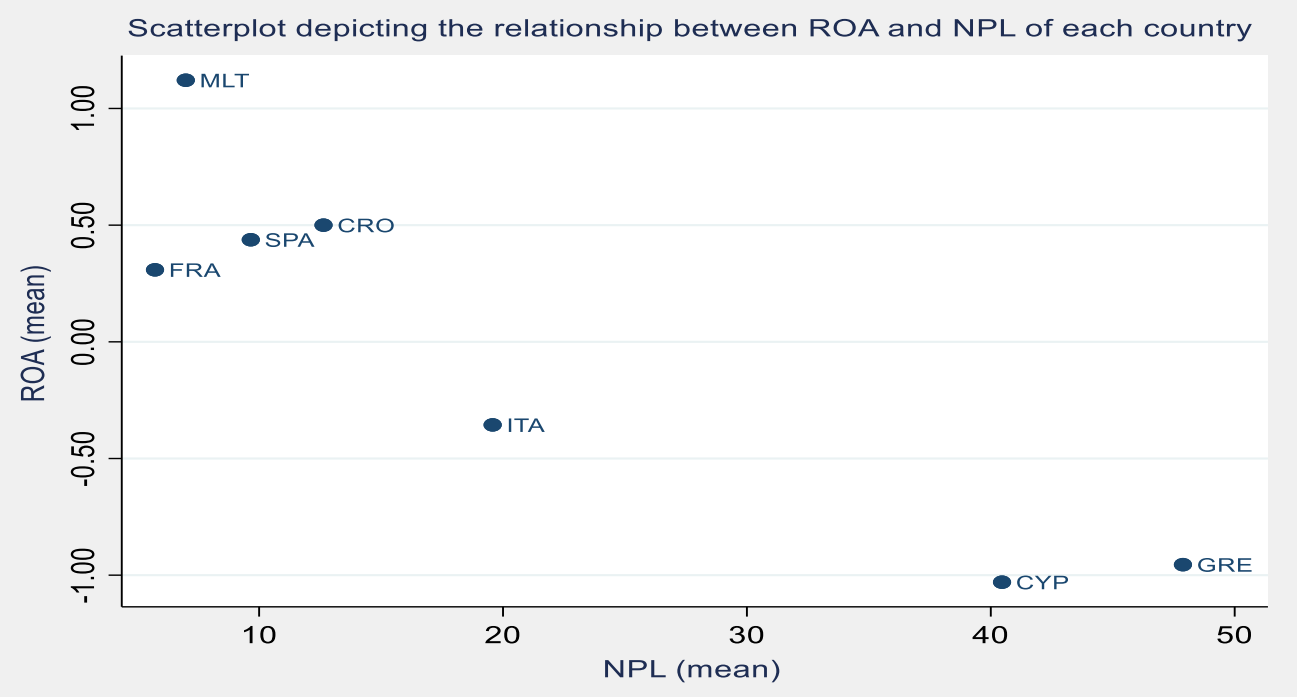

Source: Authors' Compilation.

Table 3. Shapiro-Wilk W test

Shapiro-Wilk $W$ test for normal data

\begin{tabular}{|l|l|l|l|l|}
\hline Variable & Observations & W & V & P-value \\
\hline ROA & 175 & 0.85575 & 19.166 & 0.0000 \\
\hline NPL & 175 & 0.82746 & 22.925 & 0.0000 \\
\hline LQDT & 175 & 0.83959 & 21.313 & 0.0000 \\
\hline SLVT & 175 & 0.87818 & 16.185 & 0.0000 \\
\hline
\end{tabular}

Source: Authors Compilation.

\section{Visual Inspection:}

Testing for normality also involves a visual inspection of our data and hence histograms are used in this study to further validate our hypothesis that the data in our model is not normally distributed. In the below histograms, it is visually shown that the variables NPL, LQDT, and SLVT are not normally distributed and in fact, they are skewed to the left, whereas the variable ROA is skewed to the right-hand side. Also, taking into consideration that all kurtosis figures exceed the threshold of 3 in the descriptive statistics table and as can be depicted in the below histograms, it can be shown that distributions are more peaked than those which are normally distributed and hence we can conclude that the distribution is of a leptokurtic nature i.e. not normally distributed. The histograms of the aforementioned variables are shown in Figures 5, 6, 7 and 8 respectively. 
Figure 5. Histogram showing graphically the skewness and kurtosis of the ROA's data.

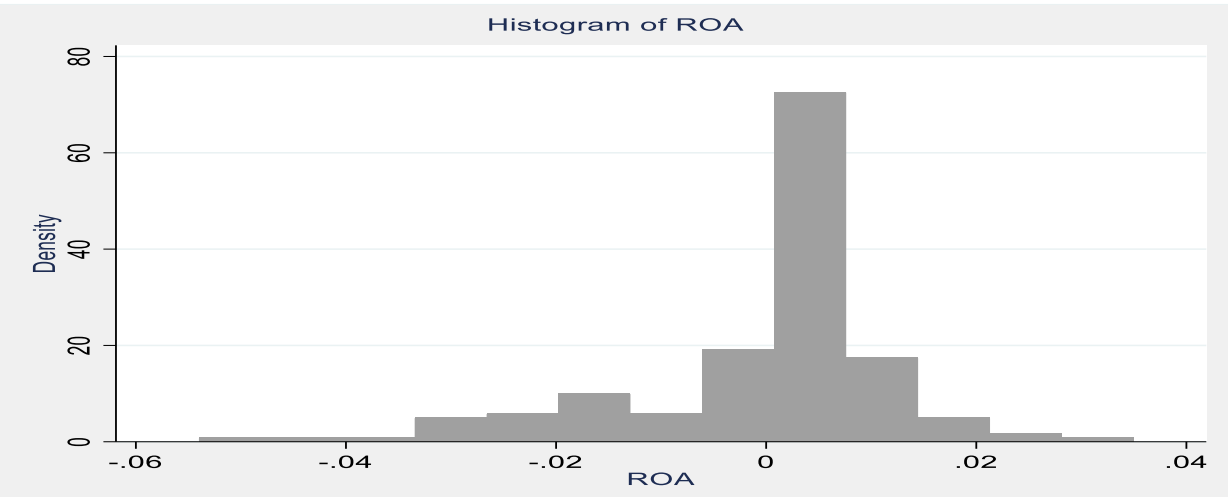

Source: Authors' Compilation.

Figure 6. Histogram showing graphically the skewness and kurtosis of the NPL's data.

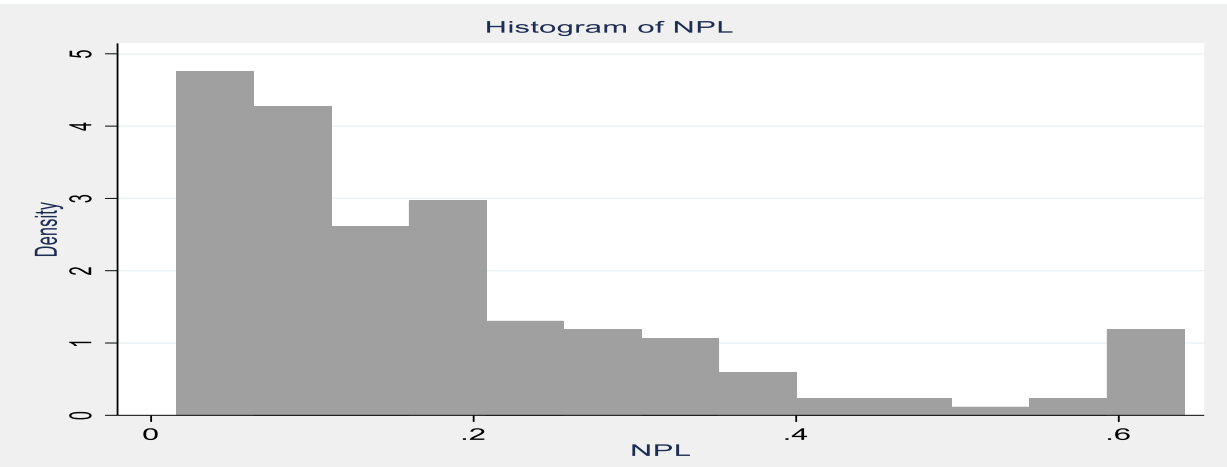

Source: Authors' Compilation.

Figure 7. Histogram showing graphically the skewness and kurtosis of the LQDT's data.

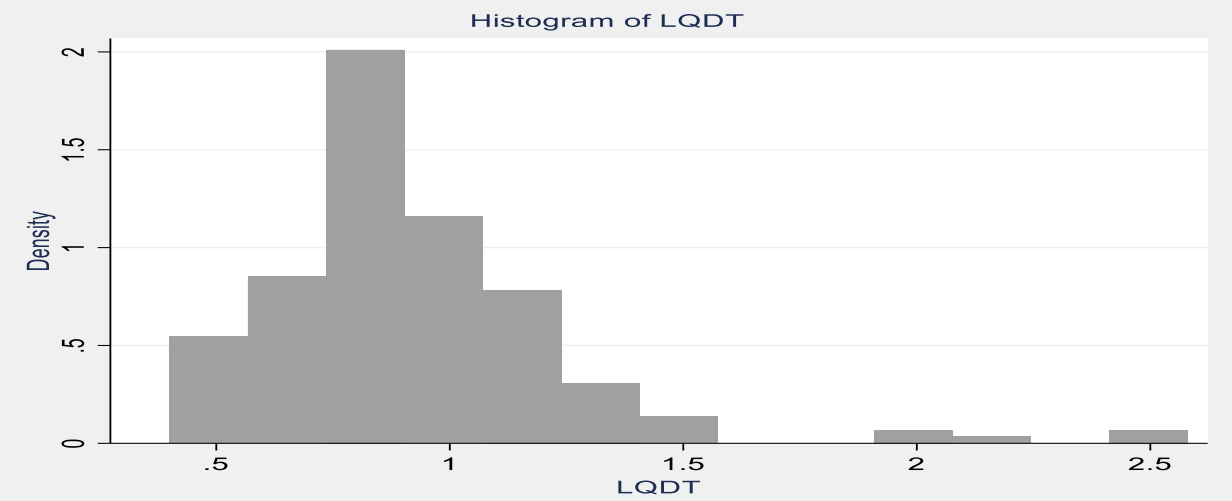

Source: Authors' Compilation. 
Figure 8. Histogram showing graphically the skewness and kurtosis of the SLVT's data.

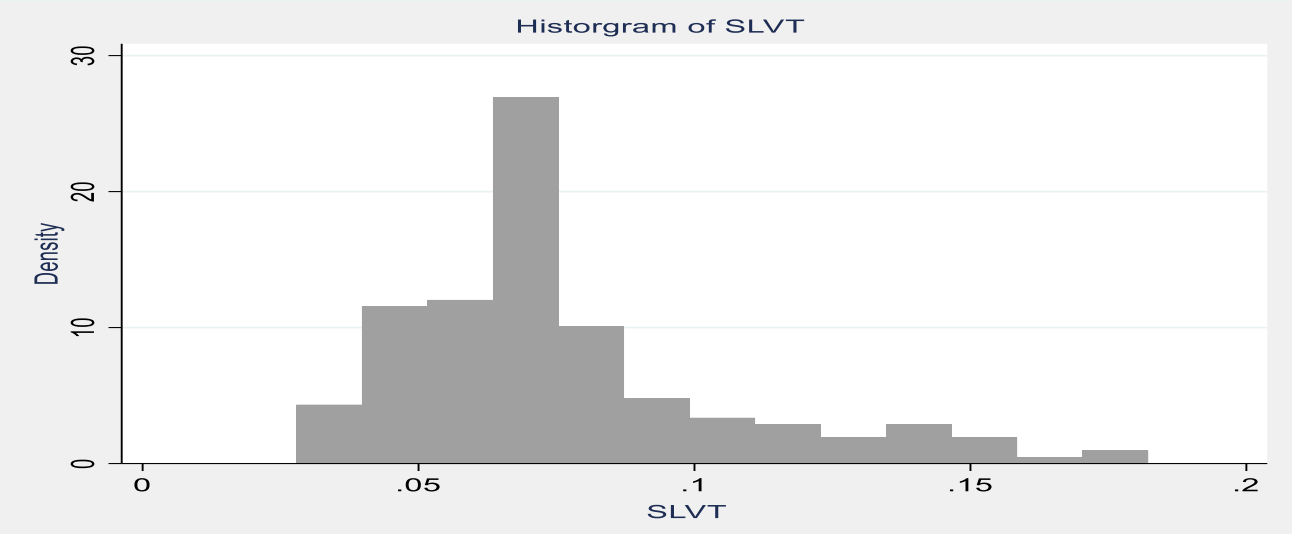

Source: Authors' Compilation.

\section{Testing for Heteroscedasticity and Serial Correlation:}

The probability value generated by the runtest resid function in STATA.IC 15.1 gives us a probability value of 0.60 which is greater than 0.05 . Therefore, we can conclude that there is no statistically significant evidence of serial correlation of the residuals in our model. In Figure 9 below we can also visually observe that serial correlation of the residuals is not persistent amongst all observations. It is evident that when the line graph spikes up it goes down again, and it continues doing the same movement up and down throughout all observations and does not remain constant in the same area for too long.

Figure 9. Line plot showing graphically the distribution of residuals along all observations

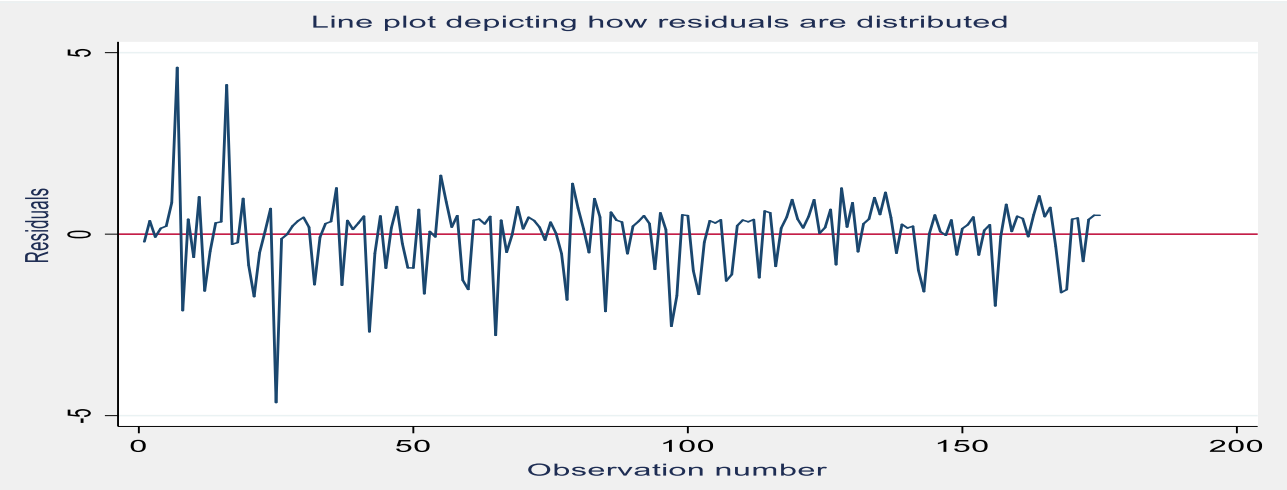

Source: Authors' Compilation.

Cluster-Robust Standard Errors test for Heteroscedasticity and Serial Correlation: After clustering our data into 35 clusters, the probability value of each test statistic for every model resulted in a value which is lower than that of 0.05 . Hence, this implies that at the 5\% level of significance, the clustered-robust standard errors test 
for heteroscedasticity and serial correlation detected no violations in the serial correlation assumptions, but conversely it detected that the presence of heteroscedasticity is present. Consequently, we conclude that it is statistically significantly proven across all models that our data does not include within panel serial correlation over time, but in some regression models used cross-panel heteroscedasticity is exhibited. Therefore, such preliminary results signify that an appropriate regression model that allows for the presence of heterogeneity is to be maintained. The aforementioned preliminary test is showed in Table 4.

Table 4. Cluster-Robust standard errors test for Heteroscedasticity and Serial Correlation

\begin{tabular}{l|lll}
\hline & Test statistic & $\begin{array}{l}\text { Test } \\
\text { value }\end{array}$ & statistic \\
\hline $\begin{array}{l}\text { Pooled } \\
\text { regression }\end{array}$ & FLS & 14.68 & 0.0000 \\
\hline Fixed Effect & F-test & 2.95 & 0.0463 \\
\hline Random Effect & Wald Chi-squared & 48.06 & 0.0000 \\
\hline Arellano-Bond & Wald Chi-squared & 30.40 & 0.0000 \\
\hline
\end{tabular}

Source: Authors' Compilation.

\subsection{Bivariate analysis of variables}

\section{Pearson r correlation test:}

The Pearson $r$ correlation was computed to show whether the presence of correlation was statistically significant amongst non-performing loans, liquidity ratio and the solvency ratio with the return on assets. The results showed that the non-performing loans ratio is significantly correlated with the return on assets whereas, the liquidity ratio and solvency ratio which act as the control variables are not correlated with the return on assets. The correlation matrix of variables determines that the nonperforming loans ratio is statistically significant at the $1 \%$ and $5 \%$ level of significance and negative with the return on assets. The results also show that both the liquidity ratio and the solvency ratio are statistically insignificant and positive with the return on assets. The correlation matrix table of all variables which impact the return on assets is illustrated in Table 5.

Table 5. Correlation matrix

\begin{tabular}{|l|l|l|l|l|}
\hline & ROA & NPL & LQDT & SLVT \\
\hline ROA & 1 & & & \\
\hline NPL & $-0.4608^{*}$ & 1 & & \\
\hline LQDT & 0.0935 & -0.1129 & 1 & \\
\hline SLVT & 0.1182 & $0.3956^{*}$ & -0.0654 & 1 \\
\hline
\end{tabular}

Source: Authors' Compilation.

Note: *Significant at the $1 \%$ and $5 \%$ level 
Furthermore, this correlation matrix shows that when the (NPL) ratio increased by 1 unit, (ROA) decreased by 0.46 ; when both the (LQDT) ratio and the equity-to-assets ratio (SLVT) increase by 1 unit respectively, the (ROA) increases by 0.09 and 0.12 respectively; when the (LQDT) increases by 1 unit, the (NPL) ratio decreases by 0.11 , whereas when the equity-to-assets (SLVT) ratio increases by 1 unit, the nonperforming loans ratio (NPL) increases by 0.40 .

Figure 10. Line of best fit showing the relationship between ROA and $N P L$

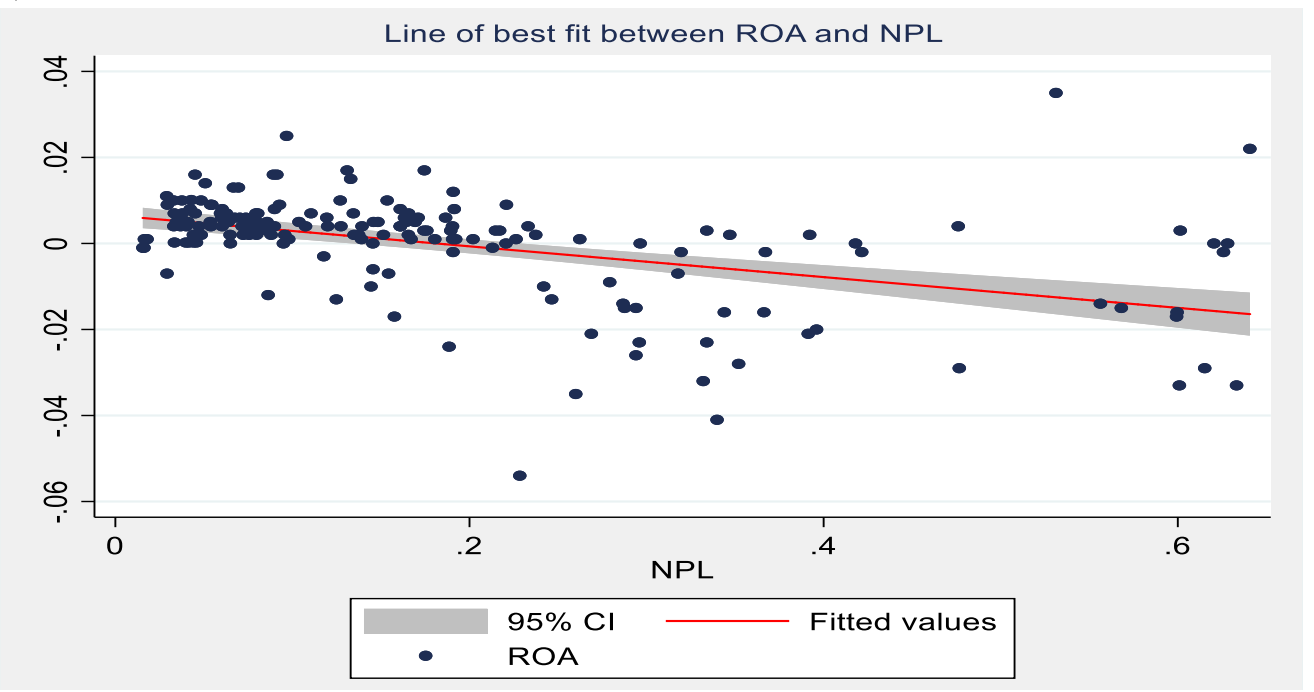

Source: Authors' Compilation.

\section{Inferential statistics:}

The regression analysis results for each model are represented in Table 6. In each of the models used, robust standard errors clustered at the bank level to account for cross-panel heteroscedasticity amongst banks and serial correlation within each bank panel were used.

In the results generated in the above table, the non-performing loans ratio (NPL) being the core explanatory variable in our model, is statistically significant in two regression models, the Pooled OLS regression model and the Random Effects model. Hence, this may indicate that there could be shortcomings in analyzing our data through the other models. It is also evident that cluster-robust standard errors are larger in the Fixed-Effects model and the Arellano-Bond model respectively when compared with those of the Pooled OLS and Random-Effects model. Such larger cluster-robust standard errors are usually common in the aforesaid models since more restrictions are placed on the moment conditions during estimation.

Results turned out to comprehend larger between-effects than within-effects hence, at the face of it the appropriate model is expected to be the Random-Effects 
estimation model. Since the Fixed-Effects estimation model assumes homogeneity which in our case this does not exist, the reasoning supporting the Random-Effects model boils down to the circumstance that this model will allow for exhibiting heterogeneity across panels. We know that the listed commercial banks representing the sample although they make part of the same region their bank population differs, therefore data used for analysis purposes is drawn from a rank of diverse populations whose differences relate to that rank. Consequently, the decision on which model is preferred is determined by looking at the results obtained through the Cluster-Robust Hausman specification test. This specification test is useful to employ when the presence of heteroscedasticity and serial correlation, or one of the two is present. Subsequently, it shows that at the 5\% level of significance the null hypothesis of this test cannot be rejected and hence we conclude that the Random Effects model is the preferred model. Results of the Cluster-Robust Hausman specification test are further shown in the Appendix.

Table 6. Regression results

\begin{tabular}{|l|l|l|l|l|}
\hline $\begin{array}{l}\text { Dependent } \\
\text { Variable } \\
(\text { ROA })\end{array}$ & $\begin{array}{l}\text { Pooled OLS } \\
\text { (Model 1) }\end{array}$ & $\begin{array}{l}\text { Fixed Effects } \\
\text { (Model 2) }\end{array}$ & $\begin{array}{l}\text { Random } \\
\text { Effects (Model } \\
\text { 3) }\end{array}$ & $\begin{array}{l}\text { Arellano- } \\
\text { Bond (Model } \\
\text { 4) }\end{array}$ \\
\hline \multirow{3}{*}{ NPL } & $-0.0463^{*}$ & -0.0006 & $-0.0448^{*}$ & -0.0079 \\
\cline { 2 - 5 } & $(0.008)$ & $(0.031)$ & $(0.008)$ & $(0.036)$ \\
\hline \multirow{3}{*}{ LQDT } & 0.0018 & 0.0021 & 0.0021 & 0.0147 \\
\cline { 2 - 5 } SLVT & $(0.001)$ & $(0.007)$ & $(0.002)$ & $(0.008)$ \\
\cline { 2 - 5 } & $0.1451^{*}$ & $0.2579^{*}$ & $0.1583^{*}$ & $0.4284^{*}$ \\
\hline
\end{tabular}

Note: *Significant at the 5\% level. Cluster-Robust standard errors are showed in parentheses.

Source: Authors' Compilation.

Furthermore, it was argued that the Pooled OLS regression model is also a potentially acceptable model, therefore the Breusch-Pagan Lagrange Multiplier (LM) test was executed to determine which model is the appropriate one between the Pooled OLS and the Random-Effects model. The Breusch-Pagan test produced a Chi-square test statistic result of 86.39 at degrees of freedom equal to 3 , which in turn resulted in a probability value of 0.000 . Hence, at the $1 \%$ level of significance we reject the null hypothesis of the test that there is any homogeneity in our sample and conclude that since the homogeneity assumption is violated, the relevant and acceptable model to be maintained in this study is the Random-Effects model.

Additionally, in all models, the (NPL) ratio manages to exhibit a negative relationship with the (ROA), resulting in a negative coefficient value. Therefore, this further validates the economic theory of negative relationship between (NPL) and profitability (ROA), meaning that as the level of (NPL) in a listed commercial bank increases, the level of return on assets (ROA) decreases, as a result of the 
mentioned negative association amongst variables. This negative relationship, amongst return on assets (ROA) and (NPL) is consistent with the findings of Akter and Roy (2017), Anastasiou, Louri and Tsionas (2016), Kingu, Macha and Gwahula (2018), Kirui (2014), Messai and Jouini (2013), and Petkovski, Kjosevski and Jovanovski (2018). Hence, as Anastasiou, Louri and Tsionas (2016) remarked in their findings, we can conclude that banks with a robust profitability position are willing to accept less credit risk and thus, participate in more risk-averse activities. Furthermore, consistent with the aforesaid author's findings we conclude that the null hypothesis states, that there is no significant impact of (NPLs) on the Profitability (ROA) of listed commercial banks in the Euro-Mediterranean region is rejected.

It is also noticeable that the control variables selected in this model, the liquidity ratio (LQDT) and the solvency ratio (SLVT) both produce a positive relationship amongst all regression models with the return on assets (ROA). This result is partially consistent with the findings of Kingu, Macha, and Gwahula (2018), wherein their study it was concluded that the liquidity ratio (LQDT) being the loanto-deposit ratio as well, is negative and significant for commercial banks in Tanzania. However, in this study for listed commercial banks in the EuroMediterranean region this appeared to be positive and insignificant amongst all models. Thus, we do not reject the null hypothesis that the Liquidity ratio (LQDT) cannot significantly explain the variances with (NPLs) and Profitability (ROA) of a listed commercial bank in Euro-Mediterranean region. Consequently, this is in line with the findings of Kirui (2014).

The discrepancy between the findings of this study and that of Kingu, Macha, and Gwahula (2018) is determined by the fact that their findings are based on a sample of commercial banks in one country, is Tanzania. Thereby, financial stability controls are chiefly controlled by the Bank of Tanzania which acts as their central bank. Conversely, in the context of this study, the sample of commercial banks in the Euro-Mediterranean region are spread amongst seven different countries, therefore the loan-to-deposit ratio is expected to deviate in line with the requirements of each country's financial stability, through their respective appointed authority. Despite such discrepancy, we reject the null hypothesis that the Solvency ratio (SLVT) cannot significantly explain the variances with Non-Performing Loans (NPLs) and Profitability (ROA) of a listed commercial bank in Euro-Mediterranean region. Hence, this is consistent with the findings of Kingu, Macha, and Gwahula (2018).

On the basis of the results in our study, it can be remarked that the positive association amongst profitability and the aforementioned control variables, denotes that the higher the liquidity base and the solvency of listed commercial banks in the Euro-Mediterranean region, the higher the connotation with higher (ROA). Moreover, this means that the greater the ability of a bank to turn assets into cash and to remain solvent i.e. the aptitude of a bank to meet its long-term obligations, the higher the association with higher profitability figures. 
Results also managed to conclude that the significantly accepted control variable, widely amongst all models is the solvency ratio, whereby for the context of this study the equity-to-assets ratio was used as a solvency ratio. The equity-to-assets ratio is fundamental for assessing a bank's financial leverage, which also gives the idea of the overall financial stability position of the bank in the long-run. Hence, the solvency ratio is a significantly and positively related variable, which appropriately can explain the variances with NPL and return on assets of a listed commercial bank. However, the liquidity ratio has no controlling power on NPL and no explanatory power on return on assets (Figures 11, 12, 13, 14, and 15).

Figure 11. Bar graph showing the level of NPLs (\%) among the years for each listed commercial bank

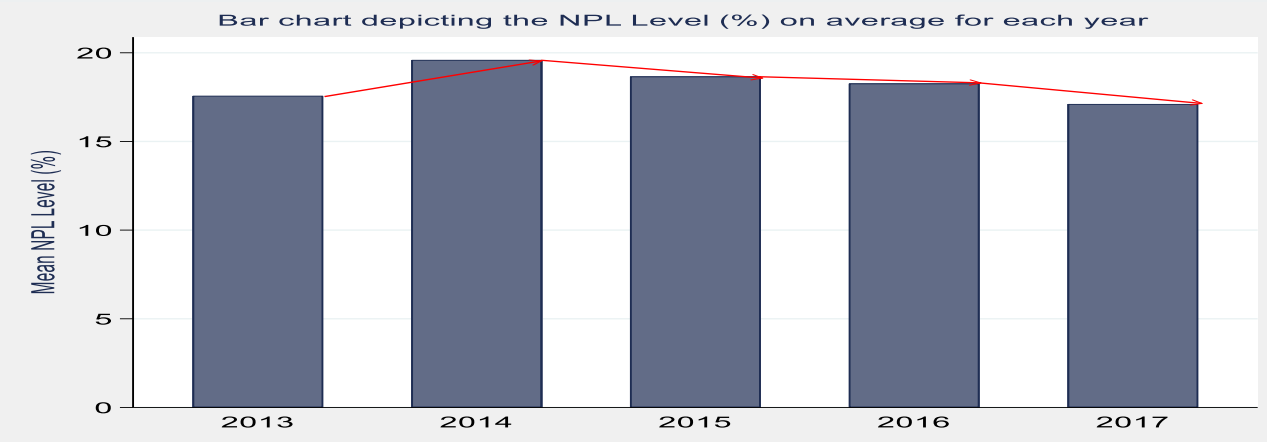

Source: Authors adapted from Thomson Reuters Eikon and Bank's respective financial statements.

Figure 12. Bar graph showing the level of NPLs (\%) for each listed commercial bank

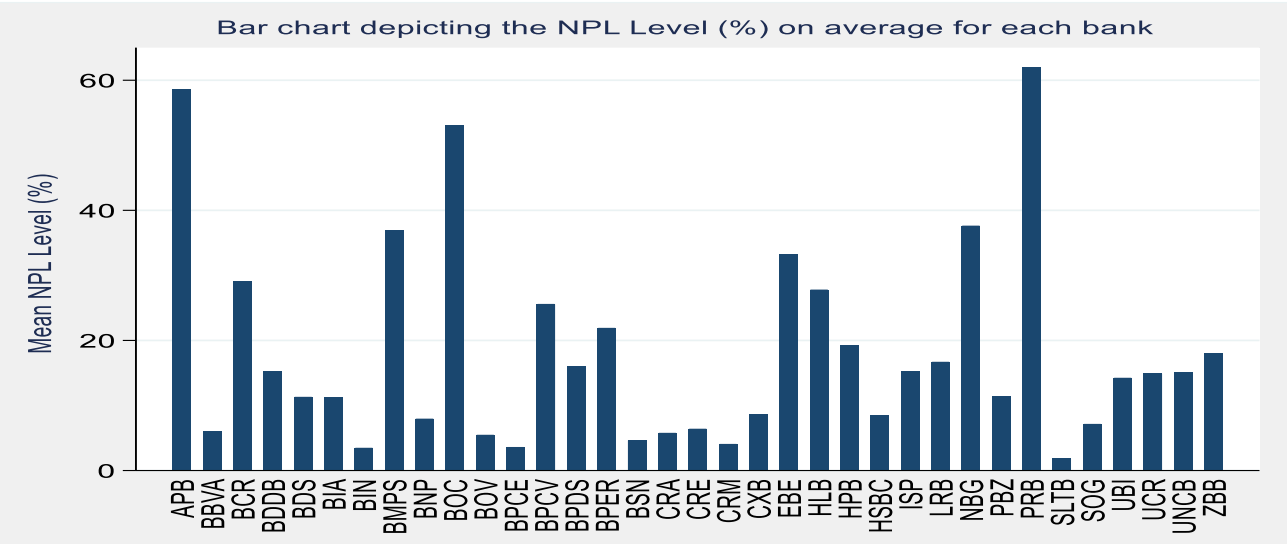

Source: Authors adapted from Thomson Reuters Eikon and Bank's respective financial statements.

The mean loan-to-deposit-ratio (LQDT) is $92.80 \%$, which is within the tolerable level of lower than $100 \%$ and thus we can consider the mean ratio as adequate. 
Furthermore, if we remove outliers from our sample and therefore give priority to the median value of such ratio, we shall conclude that on average the loan-todeposits ratio stands at $88 \%$.

Figure 13. Bar graph showing the level of NPLS (\%) for each country during 20132017.

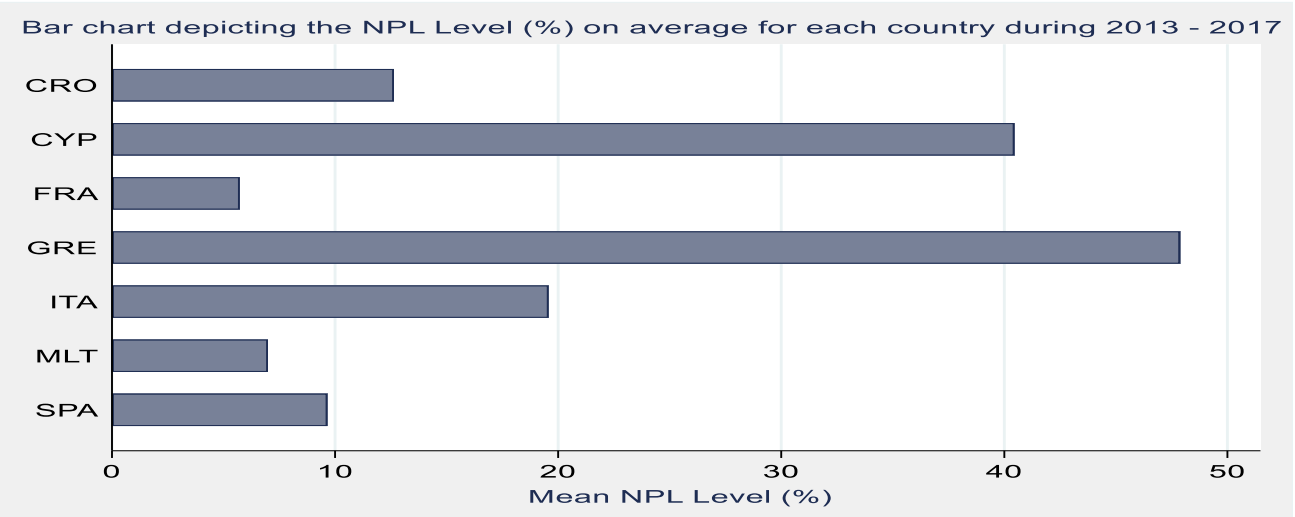

Source: Authors adapted from Thomson Reuters Eikon and Bank's respective financial statements.

The minimum loan-to-deposit ratio of $40 \%$ was realized by Bank of Valletta (BOV) in Malta, whereas the maximum ratio of $258 \%$ was realized by HSBC Malta (HSBC). Therefore, one could notice that even listed commercial banks within the same country can vary in terms of their liquidity base. The reason for such a high loan-to-deposit ratio is because, in 2016, HSBC's deposit growth contracted by $11.9 \%$ whereas, their loan growth increased by $1.3 \%$, hence leading to an exaggerated loan-to-deposit ratio. Indeed, in Figure 14 below it can be illustrated that HSBC was an outlier when considering their inflated loan-to-deposit ratio compared to the rest of the banks in the sample.

On average the solvency ratio (SLVT) ranges from a minimum of 3\% to a maximum of $18 \%$. For the context of this study the solvency ratio used, was the equity-toassets ratio, thereby a mean ratio of $8 \%$ signifies that most of the listed commercial banks in the sample only manage to finance their assets through equity by $8 \%$ on average, hence we conclude that on average the remaining $92 \%$ are financed through debt.

\section{Conclusion}

The results obtained show that in the case of the Euro-Mediterranean region, listed commercial bank's profitability is negatively impacted by NPLs. Moreover, an additional change in ROA due to the negative impact of NPLs varies according to each bank panel. 
Also, the control variable represented as LQDT was not considered to be an adequate control variable for listed commercial banks in the Euro-Mediterranean region since it was statistically insignificant throughout all regression models executed. Thus, the appropriate control variable was deemed to be that representing the SLVT i.e. the equity-to-assets ratio.The negative impact amongst NPLs and ROA indicates that, in the Euro-Mediterranean region the listed commercial bank's level of profitability is determined by the amount of credit risk being accepted. Subsequently, this demonstrates that the lesser the amount of default risk, the greater the potential for enhanced profitability figures. Correspondingly, this negative relationship raises flags for the risk management teams of the said banks, to treat in a strict and orderly manner the shortlisting of prospective borrowers to mitigate the risk of elevated credit level problems and only accept debtors with good credit repute.

In turn, this can effectively decrease the level of NPLs and increase the level of ROA simultaneously. If loan quality from previous years is left unmanaged this may indicate that there could be hypothetically a poor bank risk management function and hence, lower predictions for improved performance in the successive periods. For this to be effectively managed, commercial banks must also reduce the level of operating costs and implement further provisions for NPLs.

Figure 14. Line graphs showing individually the level of NPLs and ROA simultaneously

Line graphs depiciting the level of ROA and NPL over the years for each bank
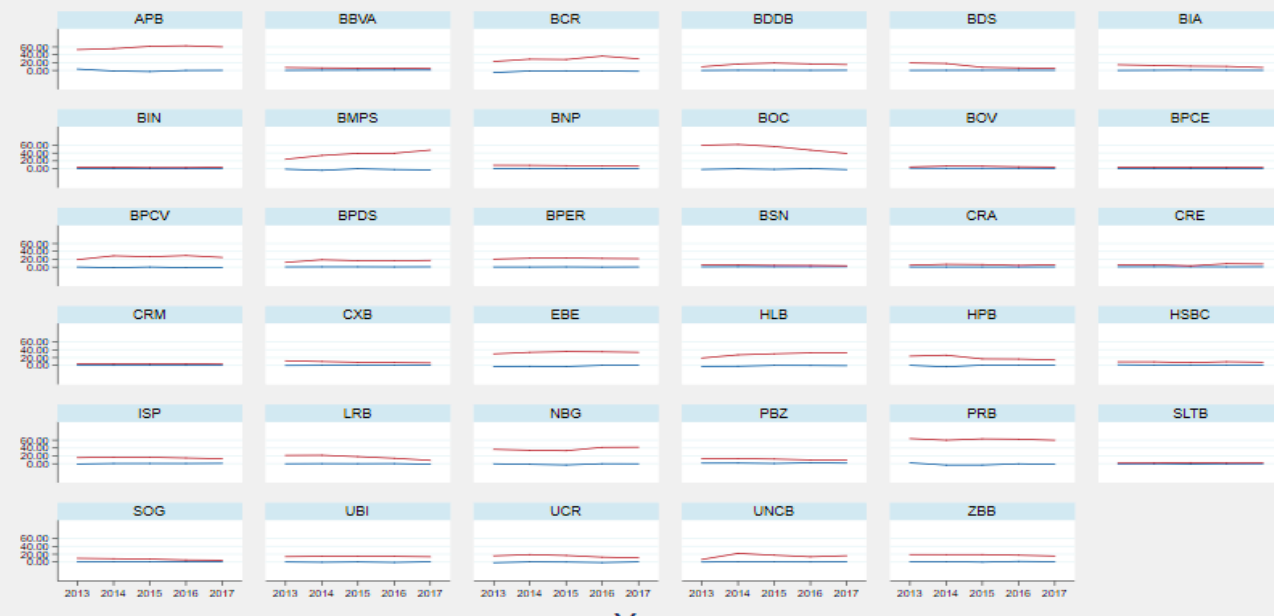

EBE
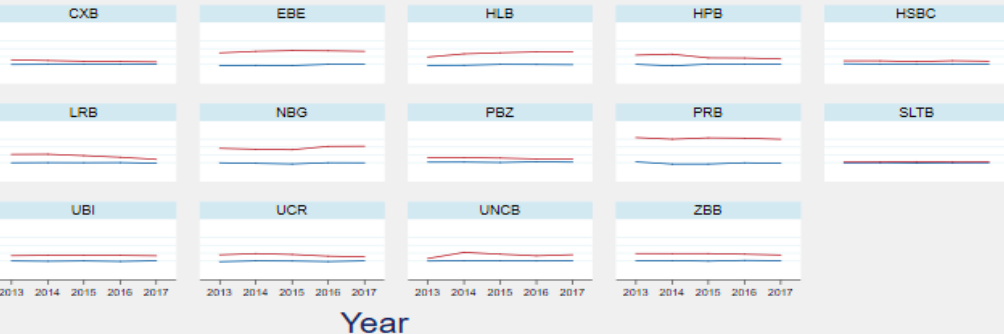

$$
\text { Year }
$$

ROA NPL

Graphs by Bank Code

Source: Authors adapted from Thomson Reuters Eikon and Bank's respective financial statements. 
Figure 15. Bar graph showing the level of loan-to-deposits ratio (LDR) for each listed commercial bank

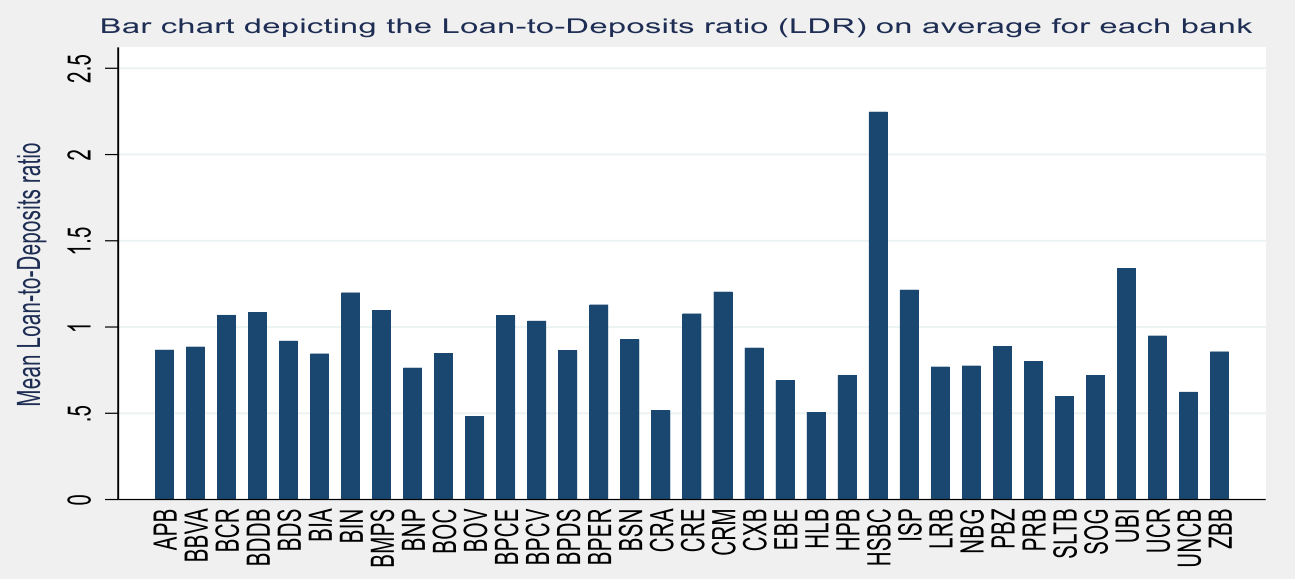

Source: Authors adapted from Thomson Reuters Eikon and Bank's respective financial statements.

\section{References:}

Akter, R., and Roy, J.K. 2017. Non-Performing Loan on Profitability: Evidence from Banking Sector of Dhaka Stock Exchange. International Journal of Economics and Finance; 9(3), pp. 126-132.

Anastasiou, D., Louri, H., Tsionas, M.E. 2016. Determinants of non-performing loans:

Evidence from Euro-area countries. Finance Research Letters, 18, 116-119.

Allison, Paul D. 2005. Causal Inference with Panel Data. Paper presented at the Annual Meeting of the American Sociological Association, August 2005.

Anbar, A. and Alper, D. 2011. Bank Specific and Macroeconomic Determinants of Commercial Bank Profitability: Empirical Evidence from Turkey. Business and Economics Research Journal, 2(2), 139-152.

Arellano, M. and Bond, S. 1991. Some Tests of Specification for Panel Data: Monte Carlo Evidence and an Application to Employment Equations. The Review of Economic Studies, 58(2), 277.

Athanasoglou, P., Brissimis, S. and Delis, M. 2005. Bank-Specific, Industry-Specific and Macroeconomic Determinants of Bank Profitability. Bank Of Greece Working Papers, (25).

Azeem, K., Khan, B., Warraich, F., Khadim, I., Zahoor, N. and Ashraf, Z. 2017. Reasons and Effects of Non Performing Loans in the Banking Industry of Pakistan. European Journal of Business and Management, 9(4).

Beck, R., Jakubik, P. and Piloiu, A. 2013. Non-Performing Loans: What Matters in Addition to the Economic Cycle? ECB Working Paper, 1515.

Breusch, T. and Pagan, A. 1980. The Lagrange Multiplier Test and its Applications to Model Specification in Econometrics. The Review of Economic Studies, 47(1), 239.

Camilleri, S.J., Grima, L., Grima, S. 2019. The effect of dividend policy on share price volatility: an analysis of Mediterranean banks' stocks. Managerial Finance, Vol. 45, Issue 2, 348-364, https://doi.org/10.1108/MF-11-2017-0451.

Căpraru, B. and Ihnatov, I. 2014. Banks' Profitability in Selected Central and Eastern 
European Countries. Procedia Economics and Finance, 16, 587-591.

Christaria, F. and Kurnia, R. 2016. The Impact of Financial Ratios, Operational Efficiency and Non-Performing Loan Towards Commercial Bank Profitability. Accounting and Finance Review (AFR), 1(1), 43-50.

Creative Research Systems. (n.d.). The survey systems. Sample Size Calculator. Online at: https://www.surveysystem.com/sscalc.htm

Cucinelli, D. 2015. The Impact of Non-performing Loans on Bank Lending Behavior: Evidence from the Italian Banking Sector. Eurasian Journal of Business and Economics, 8(16), 59-71.

Ćurak, M., Poposki, K. and Pepur, S. 2012. Profitability Determinants of the Macedonian Banking Sector in Changing Environment. Procedia - Social and Behavioral Sciences, 44, 406-416.

Demirgüç-Kunt, A. and Huizinga, H. 2000. Financial Structure and Bank Profitability. World Bank Policy Research Working Paper, 2430.

Dietrich, A. and Wanzenried, G. 2010. Determinants of Bank Profitability Before and During the Crisis: Evidence from Switzerland. Social Science Research Network (SSRN). Available at: http://papers.ssrn.com/sol3/papers.cfm?abstract_id=1370245

European Central Bank. 2016. What are non-performing loans? [online] Available at: https://www.ecb.europa.eu/explainers/tell-me/html/npl.en.html.

Eurostat. 2018. Provision of deficit and debt data for 2017 - second notification. [online] Available at: https://ec.europa.eu/eurostat/documents/2995521/9328077/222102018-AP-EN.pdf/e1b423ef-a337-42ea-90cb-4a6775ba4c07.

Greene, W. 2012. Econometric analysis. 7th ed. New York, Pearson.

Gujarati, D. 2010. Essentials of Econometrics. Boston, MA. McGraw-Hill/Irwin.

Hausman, J. 1978. Specification Tests in Econometrics. Econometrica, 46(6), 12-51.

Hepşen, A. and Vatansever, M. 2013. Determining Impacts on Non-Performing Loan Ratio in Turkey. Journal of Finance and Investment Analysis, 2(4), 119-129.

Inaba, N., Kozu, T., Sekine, T. and Nagahata, T. 2002. Non-performing loans and the real economy: Japan's experience. BIS Papers, (22).

International Monetary Fund. 2018. Euro Area Policies: Financial Sector Assessment Program-Technical Note-Systemic Risk Analysis. IMF Staff Country Reports, 18(231).

Kingu, P., Macha, D. and Gwahula, D. 2018. Impact of Non-Performing Loans on Bank's Profitability: Empirical Evidence from Commercial Banks in Tanzania. International Journal of Scientific Research and Management, 6(01).

Kirui, S. 2014. The effect of non-performing loans on the profitability of commercial banks in Kenya. MBA, project, University of Nairobi.

Kupčinskas, K. and Paškevičius, A. 2017. Key Factors of Non-Performing Loans in Baltic and Scandinavian Countries: Lessons Learned in the Last Decade. Ekonomika, 96(2).

Lipunga, A. 2014. Determinants of Profitability of Listed Commercial Banks in Developing Countries: Evidence from Malawi. Research Journal of Finance and Accounting, 5(6), 41-49.

Louzis, D., Vouldis, A. and Metaxas, V. 2012. Macroeconomic and bank-specific determinants of non-performing loans in Greece: A comparative study of mortgage, business, and consumer loan portfolios. Journal of Banking \& Finance, 36(4), 10121027.

Mazreku, I., Morina, F., Misiri, V., Spiteri, J. and Grima, S. 2018. Determinants of the Level 
of Non-Performing Loans in Commercial Banks of Transition Countries. European Research Studies Journal, 21(3), 3-13.

Messai, A. and Jouini, F. 2013. Micro and macro determinants of non-performing loans. International Journal of Economics and Financial Issues, 3(4), 852-860.

Ongore, V. and Kusa, G. 2013. Determinants of the financial performance of commercial banks in Kenya, International Journal of Economics and Financial Issues. 3(1): 237-252.

Petkovski, M., Kjosevski, J. and Jovanovski, K. 2018. Empirical Panel Analysis of NonPerforming Loans in the Czech Republic. What are their Determinants and How Strong is Their Impact on the Real Economy? Finance a úvěr-Czech Journal of Economics and Finance, 68 (5), P. 460-480.

Petria, N., Capraru, B. and Ihnatov, I. 2015. Determinants of Banks' Profitability: Evidence from EU 27 Banking Systems. Procedia Economics and Finance, 20, 518-524.

Psaila, A. 2019. The Impact of Non-Performing Loans on the profitability of listed EuroMediterranean commercial banks. Unpublished Thesis: Banking and Finance, Department of Banking and Finance, Faculty of Economics, Management and Accountancy, University of Malta, supervised by Dr. S. Grima.

Showkat, N. and Parveen, H. 2017. Non-Probability and Probability Sampling. e-PG Pathshala, Media and Communication Studies, P2M16.

Siakoulis, V. 2017. Fiscal Policy Effects on Non-Performing Loan Formation. Bank of Greece. Bank of Greece. Working Paper, (224).

The World Bank Group. 2018. Bank nonperforming loans to total gross loans (\%). Data Catalog, available at: https://datacatalog.worldbank.org/bank-nonperforming-loanstotal-gross-loans-0.

The World Bank Group. 2019. Available at: https://data.worldbank.org/indicator/FB.AST.NPER.ZSfeb.

Žiković, I.T., Žiković, S. and Blecich, A. 2015. The Drivers Behind Household and Corporate Non-performing Loans Ratio: The Case of Croatia. Privredna kretanja i ekonomska politika, 24(2), 137.

Zhang, D., Cai, J., Dickinson, D. and Kutan, A. 2016. Non-performing loans, moral hazard and regulation of the Chinese commercial banking system. Journal of Banking \& Finance, 63, 48-60. 